\title{
КОМПАРАТИВНИЙ АНАЛІЗ ДВОХ ФОРМ КИТАЙСЬКОЇ ЛІТЕРАТУРНОЇ МОВИ: ВЕНЬЯНЬ І БАЙХУА
}

\author{
Ольга ВАЛІГУРА \\ доктор філологічних наук, професор, \\ Київський національний лінгвістичний університет (УКРАЇНА) \\ e-mail: olha.valihura@gmail.com \\ https://orcid.org/0000-0003-0428-5421 \\ Ірина КОСТАНДА \\ кандидат філологічних наук, доцент \\ Київський національний лінгвістичний університет (УКРАЇНА) \\ e-mail: kostanda.iryna@ukr.net \\ УДК 811.581 .11 \\ https://orcid.org/0000-0002-5144-0941
}

DOI 10.25128/2304-1222.20.50.06

\begin{abstract}
The article examines linguistic features of two forms of Chinese literary language: wenyan and baihua. The contribution systematizes and theoretically substantiates the functioning of the wenyan and baihua languages in traditional Chinese texts. Besides, it specifies a number of their characteristics on phonetic, lexical, grammatical and stylistic language levels.

Keywords: baihua, wenyan, literary language, linguistic features, traditional Chinese texts, phonetic features.

У статті досліджуються лінгвістичні особливості двох форм китайської літературної мови: веньянь та байхуа. У роботі систематизовано та теоретичне обгрунтовано функціонування мов веньянь та байхуа у традиційних китайських текстах, а також визначено характеристики цих мов на фонетичному, лексичному, граматичному та стилістичному рівнях.

Ключові слова: байхуа, веньян, літературна мова, мовні особливості, традиційні китайські тексти, фонетичні особливості.
\end{abstract}

Artykuł analizuje cechy językowe dwóch form chińskiego języka literackiego: wenyan i baihua. Artykuł systematyzuje i teoretycznie uzasadnia funkcjonowanie języków wenyan i baihua w tradycyjnych tekstach chińskich. Poza tym określa szereg ich cech na poziomach fonetycznym, leksykalnym, gramatycznym i stylistycznym.

Słowa kluczowe: baihua, wenyan, język literacki, cechy językowe, tradycyjne teksty chińskie, cechy fonetyczne.

Постановка проблеми. Протягом останніх двох десятиліть у суспільстві відмічається все зростаючий інтерес до китайської класичної літератури, яка відображає культуру та менталітет китайського народу. Тексти давньокитайської літератури зберігають у собі важливу інформацію про соціальні, історичні, культурологічні аспекти життя людей певного періоду та пов'язані з цими аспектами лінгвістичні зміни, розвиток мови. Але розуміння та переклад давньокитайських текстів значно ускладнює той факт, що розмовна та письмова мова значно відрізнялися між собою, і така мовна ситуація зберігалася з давнини аж до 
початку XX ст. [朱汉国 2004: 25]. Окрім того, в Китаї, протягом століть, починаючи з 11 ст. до 20-х рр. ХХ ст., існувало дві письмові мови: літературна мова веньянь та мова художньої літератури байхуа. Кожна з цих мов мала свої специфічні граматичні, лексичні, стилістичні та ін. характеристики. Тому, в наш час, переклад подібних текстів вимагає від перекладача глибоких знань про лінгвістичні характеристики кожної з означених вище мов [Спирин 1976: 30].

Огляд літератури. Перші системні дослідження веньяня було зроблені китайськими лінгвістами Ма Цзяньчжуном (马 建 忠) та Ван Лі (王力) [王力 2006: с.15], які досліджували проблеми граматики веньяню, а також адаптації текстів давньокитайської мови для перекладу сучасною китайською, проблеми розвитку китайської мови та робили порівняння мови веньянь 3 іноземними мовами.

Мовні особливості давньокитайської художньої літератури були досліджені в роботах радянських синологів 50-70-х pp. Н.І. Конрада, Л.Д. Позднєвої, О.Л. Фішмана, Л.3. Ейдліна, Б.Б. Вахтіна. У другій половині XX ст. та на початку XXI ст. проблемам, пов'язаним 3 перекладом давньокитайської мови, а також розгляду граматичних та лексичних особливостей веньяню було присвячено наукові праці Л.С. Васильєвої, Ю.Л. Кроля, М.В. Крюкова, С.Р. Кучери, Е.В. Завадської, І.С. Лисевича, Л.Н. Меньшикова, А.С. Мартинова, Л.С. Переломова, Л.С. Померанцевої, .Л. Ріфтіна, В.Ф. Феоктістова, Е.М. Яншиної, М.Е. Срмакова, А.І. Кобзєва, В.В. Малявіна, Г.А. Ткаченко, Є.А. Торчинової та ін. Однак, головною вадою цих робіт є зосередження уваги на особливостях веньяню та несистематичний, або узагалі відсутній аналіз особливостей мови байхуа. Серед українських дослідників варто відзначити праці Н.С. Ісаєвої, К.Г. Мурашевич, Я.В. Шекери.

Таким чином, як ми можемо відзначити, на сьогодні уже було здійснено спроби теоретичних розробок та накопичено емпіричний досвід 3 різних аспектів мов веньянь та байхуа. Проте узагальнюючих, порівняльних лінгвістичних праць 3 давньокитайських мов веньянь та байхуа, створено не було, зокрема через відсутність систематизації накопичених знань та дисциплінарну роз'єднаність синологічних досліджень.

Наукова новизна. У статті вирішено актуальне наукове завдання, яке полягає в систематизації та теоретико-методологічному обгрунтуванні функціонування мов веньянь та байхуа.

Метою дослідження $€$ розширення знань про походження та лінгвістичні характеристики мов веньянь і байхуа та отримання нових знань про вживання цих мов шляхом проведення їх порівняльного аналізу за такими аспектами: специфіка походження, особливості вживання в літературних текстах на фонетичному, лексичному, граматичному та стилістичному мовних рівнях. 
Актуальність дослідження зумовлена необхідністю комплексного дослідження становлення та розвитку двох письмових мов давнього Китаю, а також потребою описати та систематизувати знання про функціонування та лінгвістичні характеристики мов веньянь та байхуа.

Предметом дослідження $€$ особливості походження та вживання в літературних текстах мов веньянь та байхуа, а також їх фонетичні, лексичні, граматичні та стилістичні особливості.

Методи дослідження. В роботі було використано такі методи:

- порівняльно-історичний метод (для порівняння мов байхуа та веньянь та виявлення їх спільних та розбіжних рис);

- дистрибутивний аналіз (для встановлення характеристик та функціональних властивостей досліджуваних мовних одиниць з урахуванням їх оточення та контексту);

- описовий метод для класифікації та інтерпретації досліджуваних мовних явищ;

- зіставний метод для встановлення системи розбіжностей та відповідностей на всіх рівнях мов веньянь та байхуа;

- функціональний аналіз (для дослідження особливостей вживання досліджуваних мовних одиниць в текстах веньяню та байхуа).

Теоретичну основу дослідження складають наукові праці синологів та лінгвістів: Малявіна В.В., Спіріна В.С., Дін Джиміна (丁治民), Лю Ліншен (刘 麟 生), Ван Лі (王力), Ван Юшена (王友胜), Чжан Чжунсіна (周秉钓).

\section{Виклад основного матеріалу дослідження}

Інтерес до китайської літератури зростає 3 кожним роком, китайська цивілізація зробила безцінний внесок не тільки в скарбницю світової літератури, але й для світової культури у цілому. Це обумовлено і тими особливостями китайської культури, що відображені в творах, і особливостями мови китайської класичної художньої літератури.

У Китаї до початку XX-го ст. було дві літературні мови, які співіснували разом протягом століть, кожна з яких мала свої особливості, які ми розглянемо нижче. Насамперед треба окреслити загальні особливості кожної мови у контексті специфіки походження та особливостей вживання в літературних текстах на фонетичному, лексичному, граматичному та стилістичному мовних рівнях. Тож розглянемо мови веньянь (文言) та байхуа

(白话 ) 3 точки зору означених вище аспектів.

Перш за все, для розуміння походження та формування особливостей двох літературних мов Китаю, треба розглянути (принаймні коротко) мовну ситуацію, яка склалася та продовжувала розвиватися в Китаї у період з V-III ст. до н.е. до 20-х рр. XX ст. Взаємозв'язок писемності та розмовної мови були дуже важливою проблематикою 
китайського суспільства ще з часів, коли писемна мова остаточно відірвалася від розмовної, а це сталося у середині 1 тисячоліття [Малявин 2000: 389]. 3 часом розрив між писемною та розмовною мовою ставав усе більшим, а проблема розуміння писемної мови, іiі відокремленість від розмовної, набувала все більшої гостроти. До династії Сун (宋, 9601124), упродовж багатьох віків розвитку китайської культури та літератури, всі письмові твори було записано на мові веньянь , а вплив розмовної мови було зведено до мінімуму.

За династії Сун починається становлення та розквіт міської, можна навіть сказати світської культури, що збільшує вплив розмовної мови на писемну: в XI ст. виникає жанр новел хуабень (话本) написаних на світську тематику [张再峰 2011: 54], як можна зазначити навіть із назви, ці новели було написано розмовною мовою. Поява новел хуабень зробила, свого роду, «мовну революцію або мовний переворот»: з цього часу до письмової мови починають додаватися багато елементів розмовної (синтаксис, лексика). За династії Юань (元, 1279-1368), писемна мова ще більше наблизилась до розмовної завдячуючи розквіту драматургії [张再峰 2011: 69]: мова театральних персонажів, що звучить зі сцени, повинна була стати зрозумілою та менш архаїзованою для широких кіл глядачів. В цей час розмовна та письмова мови утворюють новий різновид писемної мови байхуа [张再峰 2011: 134]. Починаючи з XIII ст. у наступні століття, включно 3 початком XX ст., мова байхуа стає мовою таких прозаїчних жанрів літератури як п’єси, новели, романи. Але, навіть з великою кількістю розмовних елементів, мова байхуа усе одно містить значну частину елементів 3 веньянь [谢鲁 2010: 172]. Через те, що мова байхуа відображала у текстах розмовну мову певного часового періоду, вона активно вбирала та зафіксовувала зміни, пов’язані з лексикою, граматикою та структурною побудовою тексту. До того ж, для мови байхуа існував ще один додатковий чинник, який впливав на зміни цієї письмової мови: велика кількість діалектів, що у всі періоди існували на території Китаю. Але навіть за відсутності єдиного граматичного та лексичного стандарту, сталих правил для побудови тексту (всього, що було дійсним для мови веньянь), в історії китайської мови традиційно виділяють чотири найбільш поширені різновиди мови байхуа [张中行 1988: 82]:

- ньбай «римована розмовна мова» (韵白);

- цзінбай «пекінська розмовна мова» (京白);

- субай «сучжоуська розмовна мова» (苏白);

- гуаньбай «гуанчжоська розмовна мова» (广白). 
Усі означені вище різновиди було зафіксовано у текстах різнопланової тематики, різних часових зрізів. Тож, розглянемо детальніше особливості походження та використання кожного з чотирьох видів мови байхуа.

1. Юньбай. Основою для юньбай став фонологічний стандарт римування, який виник та почав розвиватися за династії Юань, на тлі відомої праці «Рими центральної рівнини» («中原音韵》) [丁治民 2009: 29]. За династії Мін на фонологічні особливості юньбай вплинула ще одна праця чиновників династії Мін «Правильні рими Хунву» («洪武正韵») [朱汉国 2004: 18]. У цій науковій роботі, за фонологічний стандарт було взято вимову чиновників династії Мін (明 1368-1644). Тут слід зазначити, що у період правління династії Мін, найбільш розповсюдженими, як серед простого населення, так і серед чиновників, були хубейський, хуннанський та гуандунський діалекти. I саме лексику та фонологічні особливості цих діалектів було відображено в усіх наукових філологічних працях та словниках рим того часу. Відображення мовних особливостей цих трьох діалектів ми можемо зараз побачити у текстах драм династії Мін, записаних на юньбай. Однак, після того як правління країною перейшло до династії Цинь, головним розмовним стандартом став пекінський діалект, тож юньбай почала звільняти місце цзінбай, своє існування вона продовжила лише у текстах драматичних творів записаних у династію Цинь, а саме у пекінській опері (京剧) та у опері куньку (昆曲), де юньбай використовується для промов та окремих реплік [谢鲁 2002: 164].

2. Цзінбай, перекладається як «розмовна пекінська мова», в своїй основі має пекінський діалект. Фонетичну систему римування створену на основі цзінбай в той час (правління династії Цинь 1644-1911 ) називали «новою фонетичною системою» («新音系») [谢鲁 2002: 247]. Поступово цзінбай, у загальному вжитку, повністю замінює хубейський, хуннанський та гуандунський діалекти, а також починає активно використовуватися для запису текстів пекінської опери.

3. Субай, перекладається як «сучжоуська розмовна мова», в іiі основі лежить діалект міста Сучжоу, але вона також відображає мовні особливості провінцій Цзянсу та Чжецзян. Історично склалося, що у цих двох провінціях існувала велика кількість діалектів, тож субай використовувалася в ті часи як єдиний мовний стандарт для названих вище провінцій [谢鲁 2002: 289]. Згодом субай увібрала в себе мовні особливості інших локальних діалектів. Через те, що на півдні Китаю відбувалось значно менше війн та майже не відчувалося впливу іноземних князівств та держав, діалекти Цзянсу та Чжецзяна зберегли свою традиційну фонетичну систему (однією з фонологічних особливостей цих діалектів $\epsilon$ збереження дзвінких приголосних) та граматичну структуру мови, дуже наближеної до класичної, котра відображена утекстах записаних на веньянь. Ця відображена у субай 
канонічність мови згодом привернула до себе цинську інтелігенцію та стала використовуватися багатьма чиновниками того часу. Субай також використовувалася в діалогових текстах опери куньцю.

4. Гуанбай перекладається як «розмовна мова міста Гуанчжоу», основою гуанбай став діалект міста Гуанчжоу. Фонетичну систему гуанбай називають «класичною фонетичною системою» (旧音系), на відміну від «нової фонетичної системи» створеної на основі пекінського діалекту за часів цинської династії, особливості притаманні цій фонетичній системі було відображено ще за династії Сун у філологічній праці «Рими гуанчжоуської мови» («广韵») [周秉钓 1955: 235]. Через географічні особливості гуанбай довгий час існувала самостійно, без впливу інших мов та діалектів (зокрема пекінського), тож її вдалося зберегти в собі мовні особливості, притаманні текстам династії Цинь.

Розглянуті вище чотири різновиди розмовної мови зафіксовано у багатьох пам'ятках художньої літератури, а саме [张再峰 2011: 48]:

- $\quad$ у пекінській опері використовуються цзінбай та юнбай;

- в опері кунцю використовується юнбай та субай;

- в опері Ює використовується субай;

- кантонській опері використовується гуанбай.

Однак було би помилкою стверджувати, що у художній літературі використовувалися лише ці чотири види байхуа. Так чотири видатні романи китайської літератури використовують провідною мовою цзінбай, але відзначається також вплив інших діалектів. Наприклад, у романі Цао Сюециня «Сон у червоному теремі»(曹雪芹《红楼梦») більша частина тексту записана на цзінхуа, але також присутня значна частина субай, та зустрічаються елементи гуанбай.

Слід зазначити, що у першій половині 20 ст. термін байхуа почав використовуватися лише для назви розмовної мови династії Цинь, назви всіх інших видів замінило слово «діалект» [王力 2006: 180].

Тож, як бачимо, структура байхуа, упродовж усього часу ii існування, ніколи не лишалася сталою, а збагачувалась та змінювалася, відображаючи певні історичні, соціокультурні зміни. Тексти записані цією мовою можуть надати лінгвістам багато інформації про певний історичний період.

3 появою двох літературних письмових мов у тогочасному Китаї одразу виникає розподіл письмових текстів на «високу» та «низьку» літератури [Малявин 2000: 395]. Критеріями для цього розподілу була тематика тексту, саме від неї залежав вибір мови для запису тексту та визначалась приналежність тексту до «високої» чи «низької» літератури. «Висока література» записувалася на веньяні та висвітлювала тематику служіння державі, 
імператору, почуття боргу перед державою, суспільством, героїзм, філософське переосмислення буття та ін. Тематика, якої не повинно бути взагалі в високій літературі - це тематика кохання, еротизм, побутові, сімейні стосунки та проблеми, тощо. «Високу літературу» Китаю до XX ст. можна поділити на такі різновиди: історичні тексти, релігійнофілософські тексти, політичну публіцистика та ін.

«Низька література», для запису якої використовували байхуа - це романи, драми, новели, вірші: усе, що висвітлювало тематику кохання, еротизму, сімейних стосунків та конфліктів.

У мові веньянь використовувались такі стилістичні прийоми: метафора 比喻, уособлення 比拟、метонімія 借代, гіпербола 夸张, створення багатозначності 双关, «запитання-гіпотеза » 设问, паралелізм та його різновиди对仗, повтор 反复, використання лаконізмів 简练, алюзій 典故 та ін. [周秉钓 1955: 192]

У байхуа використовувались усі притаманні мові веньянь стилістичні прийоми. Однак, слід відзначити, що алюзії використовувались у байхуа набагато менше, чим у веньянь. Замість висловів відомих людей та алюзій до відомих творів, у байхуа використовувались прислів'я та приказки. Стилістичним прийомом, що дуже рідко зустрічається у мові байхуа, $є$ використання лаконізмів: байхуа тяжіє до розлогої оповіді через яскраві, кольорові описи, тож вживання лаконізмів йде всупереч з естетичною метою байхуа.

Граматика мови веньянь будується на двох головних чинниках - порядок слів у реченні та службові слова. Саме через ці чинники у письмовій мові можна виділити сталі правила для порядку слів у реченні [蒲立本 2005: 158]:присудок йде після підмета; додаток йде після підмета; означення ставиться перед означуваним словом; об'єкт або обставина місця ставиться після присудку або після спеціального прийменника.

Однак існують особливі типи речень, які також мають фіксований порядок слів, що суттєво відрізняється від класичного. Речення нижче розглянутих типів дуже широко розповсюджені у мові веньянь, тож не можна обійти увагою специфіку їх структури та вживання [Спирин 1976: 64], [蒲立本 2005: 73].

1. «Речення-судження» 判断句: розповідне речення 3 іменним присудком. Найчастіше для побудови цього типу речень вживаються такі конструкції:

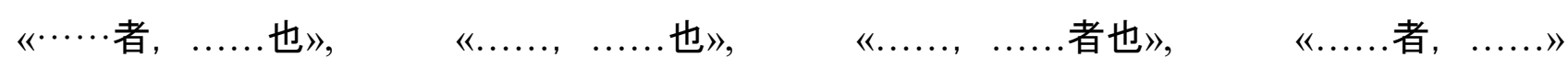
«.....者, ......者也»[周秉钓, 1955: 470]. 
Також для утворення «речення-судження» вживаються прислівники: «乃», «即», «则», 《皆》, 《是》, 《诚》, 《为》 [张中行 1988: 165].

2. Речення пасивного стану 被动句. Найчастіше речення цього типу будуються завдяки конструкціям та службовим словам: «见», «...... 见.....于», «于», 《为», «为......所».

3. Речення з інверсією 倒装句. Таких речень розрізняють декілька типів, а саме речення 3 інверсією обставини місця 宾语前置, речення 3 інверсією означення 定语后置, речення з інверсією обставини 状语后置, речення з інверсією присудка 谓倒装.

4. Речення зі скороченим підметом省略主语.

5. Речення зі скороченим додатком.

6. Речення з двома додатками.

7. Речення 3 фіксованим елементами та конструкціями 《固定结构》: 奈何》, 《若何》, 《如何》, 《何如》, 《奈......何》, 《若......何》, 《如(奈)......何》, 《孰与》, 《得无.....乎》, 《孰若》, 《何...之有》, 《何以......为》, 《何......为》, 《不亦......乎》, 《无乃.....乎》, 《得无......乎》.

Окрім цих особливостей, слід зазначити, що на розташування слів у реченні мови веньянь, впливають службові слова, так звані «пусті слова», завдяки яким стає можливим порушення прийнятого порядку слів.

Мову байхуа, зазначимо це ще раз, формувало два чинника: письмова мова веньянь та розмовна мова певного часового відрізку. Тому, на першому етапі свого формування, мова байхуа перейняла всі притаманні веньяню граматичні особливості. Але згодом, через те, що байхуа, що видно з самої назви («проста/розмовна мова»), тяжіє до відображення у письмових текстах розмовних елементів, відбулося часткове спрощення граматичних конструкцій, тобто певні граматичні конструкції мови веньянь (наприклад речення 3 фіксованими конструкціями, речення зі скороченим додатком) стали рідше вживатися у текстах байхуа. Але, з більшою або меншою частотою вживаності, у байхуа відображено всі граматичні конструкції мови веньянь.

Що стосується лексичних особливостей мови веньянь, то треба відзначити таке: переважна більшість слів веньяня складали односкладові, однокореневі слова; більшість слів веньяню були багатофункціональними, залежно від свого місця у реченні мали різне значення.

У веньяні існував традиційний розподіл на повнозначні слова або «справжні слова» (实词) та службові слова або «пусті слова» (虚词). До повнозначних слів у мові веньянь належать [刘麟生著 1998: 167]: ієрогліфи 3 предметним значенням;ієрогліфи зі значенням характеристики людини, предмету, явища та ін.;ієрогліфи, що позначають дію; власні назви. 
У мові байхуа зберігається розподіл лексики на «справжні слова» та «пусті слова», але з'являться тенденція до двоскладових або багатоскладових слів, що суттєво полегшує розуміння значення слова у реченні зокрема та видаляє зайву багатозначність слова загалом.

Отже, у результаті здійсненого дослідження ми отримали такі результати:

Веньянь є рафінованою мовою, особливо з позицій стилістики, ця мова намагалася оминути будь-які прояви спонтанності мовної передачі та уникнути впливу розмовної мови. Зокрема, завдяки такому стилістичному прийому, як алюзія, дуже широко розповсюдженому у мові веньянь, відбувалося постійне повернення до класичних творів, висловів відомих людей, що призводило не лише до повтору певних думок та ідей, а й до повтору лексики та граматичних конструкцій.

На відміну від мови веньянь, мова байхуа, протягом всього свого розвитку постійно змінювалась завдяки фіксуванню лексики та зворотів розмовної мови (особливо цьому сприяло активне використання у текстах байхуа прислів’їв, приказок та яскравих простонародних виразів). Веньянь і байхуа відрізняються стилем викладу: у веньяні «витончений стиль» (雅 «я»), а у байхуа розмовний або простий (俗 «су»). У байхуа використовується велика кількість простонародний слів і яскравих простонародних виразів;

Веньянь має сталу, сформовану організацію мовних одиниць на всіх рівнях: фонетичному, лексичному, граматичному та ін. Ця мова протягом віків залишалась сталою, дуже вибірково та повільно приймає будь-які зміни.

Мова байхуа постійно змінювалась на всіх мовних рівнях протягом всіх етапів свого існування, відображаючи в собі всі історичні, культурні та соціальні зміни. Існувало декілька різновидів мови байхуа, які відображали, окрім іншого, діалектну лексику та граматику.

Веньянь і байхуа розрізняються структурою лексики: у мові веньянь лексика односкладова, у байхуа є тенденція до двоскладових слів, яка укоренилася в сучасній китайській мови.

Веньянь та байхуа мають багато спільного з точки зору граматики: для обох цих мов важливий порядок слів у реченні та особливості вживання службових слів. Як було зазначено вище, граматика веньянь була взята за основу для байхуа, але згодом, під впливом розмовної мови, діалектів, не всі граматичні конструкції веньяня з однаковою частотою вживаються в байхуа.

Найбільш важливим спостереженням, отриманим у результаті досліджння є таке: веньянь - це мова для передачі змісту, яка прагне до найбільш можливої стислості викладу (тому тексти в перекладі з мови веньянь виходять значно довші оригіналу), байхуа - це мова для передачі емоційності і виразності оповідання, вона має характерні описові звороти i барвисту лексику для створення довгих розлогих описів, часто можливі повтори однієї думки різними словами для посилення художнього ефекту. Таким чином, наше дослідження 
надає додаткові знання для перекладачів, що шукають стратегії перекладу китайських традиційних текстів.

Отримані результати не суперечать тим дослідженням, що вже були зроблені західними та вітчизняними синологами, але розширюють уявлення про історію формування літературних мов Китаю, про фонетичну систему мови байхуа та стилістичні аспекти мов веньянь та байхуа.

Висновки. Зі всього означеного вище можна побачити, наскільки складним був шлях формування у Китаї писемної літературної мови та наскільки важливим було використання мов веньянь та бахуа для певного виду традиційних текстів, наскільки складною $\epsilon$ структурна система кожної з означених вище мов. Систематизація та конкретизація низки теоретичних визначень та характеристик мов веньянь та байхуа може надати новий поштовх для переосмислення значення літературних мов у культурі Китаю загалом, та у формуванні сучасних особливостей китайської літературної мови зокрема, а також на основі результатів дослідження можуть будуватися нові стратегії перекладу з давньокитайської мови.

\section{ЛIТЕРАТУРА}

Малявин, В.В. (2000), Китайская цивилизация. Москва [Malyavin, V.V. (2000), Kitayskaya tsivilizatsiya. Moskva].

Спирин, В.С. (1976), Построение древнекитайских текстов. Москва [Spirin, V.S. (1976), Postroenie drevnekitayskikh tekstov. Moskva].

丁治民（2009）从《韵会定正》论《洪武正韵》的得失 - 兼论明太祖“中原雅音”的性. 北京： 语言科学.

刘麟生著, (1998). 中国骈文史 (中国文化史丛书). 北京 : 商务印书馆.

蒲立本, (2005). 古汉语语法纲要. 北京 : 语文出版社.

王力, (2006). 古代汉语. 北京: 首都教育出版社.

王友胜, (2010). 民国间古代文学研究名著导读. 上海 : 岳麓书社.

谢鲁, (2002). 京剧“韵白”的“声”、“韵”、“调”：戏剧之家. 北京：首都教育出版社.

张再峰, (2011). 中州韵和湖广音：中国戏剧, 北京 : 首都教育出版社.

张中行, (1988). 文言与白话. 黑龙江: 黑龙江出版社.

周秉钓, (1955). 古汉语自学手册/ 周秉钓. - 湖南 : 湖南任命出版社.

朱汉国,

(2004)。普通高中课程标准实验教科书厉史

（必修三·思想文化专题史）。北京：人民出版社. 